\title{
ADOPTION OF SOYBEAN PRODUCTS IN OWERRI NORTH LOCAL GOVERNMENT AREA OF IMO STATE, NIGERIA
}

\author{
EDNA C. MATTHEWS-NJOKU, \\ Department of Agricultural Extension \\ Federal University of Technology, PMB 1526, Owerri, Imo State \\ Email: dredna04@yahoo.co.uk
}

\begin{abstract}
Soybean products are important in the household nutrition programme because of their high protein content and their affordability. The objectives of this study include examining adoption of soybean products in Owerri North local government area of Imo State, Nigeria, describing the socio-economic characteristics of respondents in the study area and determining the relationship between adoption and socio-economic characteristics of respondents. Thirty randomly selected respondents who were administered with structured questionnaire using interview schedule were involved in this study. Data analysis was by use of frequency, percentage and chi square. Finding of the study revealed that adoption of soybean products was high as respondents (57\%) utilized soybean products three times a week. Findings further revealed that $33.3 \%$ of the respondents were between 41 and 50 years old, 40\% had household size of between 3 and 6 members. The study revealed that majority of the respondents were females, were married and were farmers. The chi square results showed that household size, education, gender and marital status significantly influenced adoption of soybean products. Based on the findings of the study it is recommended that Agricultural extension agents, especially Home economics extensionists should intensify efforts to teach rural women and others the proper production methods of the various soybean products especially soymilk which did not record high adoption.
\end{abstract}

Key words: adoption, Imo State, Owerri North, Nigeria, soybean products

\section{INTRODUCTION}

There is no gainsaying that the level of food wastage at the farm family level is enormous. This is obviously because of the inadequate and mostly lack of adequate storage facilities. A huge proportion of farm produce is lost through wastage. The need to expose farm families to information on the means of storing agricultural produce therefore becomes necessary. Many farm families consume less of animal protein because they cannot afford the high cost of the products. In many parts of the Third world there is not enough protein for healthy human diet. The reason may be a shortage of protein but also a poor quality of the available protein, so that it is of little value in the diet (Agrodok, undated). Plant protein sources are however cheaper and one of such plants soybean. Soybean is an important staple food of great nutritional value. Its importance ranges from milk production, oil processing, livestock feeds, industrial uses, human consumption and medical uses (Addo and Oguntona, 1993; Adedoyin, et al 1998). According to IITA (1990) soybean and its products is less expensive compared to other animal proteins sources such as eggs, beef, and milk. Soybean is therefore an alternative to these expensive protein products. 
Soybean (Glycine max) is native to East Asia and ranks high among the leguminous crops of the world both in its content and nutritional value. It contains more protein than about (40\%) than most legumes, but less fat (about 18\%) than most oil seeds (IITA, 1984). It has been cultivated for many years in China, Japan and other countries of the East and South East Asia where it contributes substantially to their diets.

In Nigeria, soybean is relatively new but the International Institute of Tropical Agriculture (IITA) has made tremendous research advances on the crop. Since 1985 soybean food products have been an important part of the Institute's Soybean research programme. The Federal Government of Nigeria became interested in the programme and then made funds available for it. The major aim was to develop appropriate soybean technology for household use and also, small scale ventures. Various products can be produced from soybean for food purposes and such products include soybean flour, soymilk, soy moi moi, etc for human and livestock consumption. The importance of soybean in the nutrition programme the average farm family is without doubt. Singh et al (1987) reported that soybean production in Nigeria is increasing, while Adekunle et al (2003) observed that World production statistics have it that Nigeria is the second largest producer of soybean in Africa after Zimbabwe.

The Imo Agricultural Development Programme carried out several trainings on the production and processing of soybean. The training on production of various soybean products was done to benefit especially the resource poor who may not be able to afford the costly animal protein products. As a result of the training the need to determine the utilization of soybean products becomes very necessary so as to identify whether the training was justified. This study therefore investigates the adoption of soybean products among inhabitants of Owerri North local government area. The study describes the socioeconomic characteristics of respondents involved in the study, and also determines the relationship between adoption of soybean products and the socio-economic characteristics of respondents.

\section{METHODOLOGY}

Imo State is one of the States in South Eastern Nigeria. With a total landmass of about 25, 289.46 $\mathrm{km}^{2}$, and a population of about 2, 485, 499 (National Population Commission, 1992). The State is bounded in the East by Abia State, on the North by Anambra State, on the West by Delta State and on the South by Rivers State. The State is made up of 27 local government areas, and based on the ADP zoning into three agricultural zones namely Orlu, Owerri and Okigwe zones. From the three zones Owerri zone was purposively selected for the study and Owerri North local government area was selected for the study because the ADP in the area had carried out intensive training on soybean. The vegetation of the area is typical of a rainforest region and the soil conducive for the growth of the legume. The area experiences a dry season from October to March, and a wet season from April to September, with two peak periods in July and September, and a break in mid August. The people of the area are predominantly farmers and also traders. 
A list of registered farmers in Owerri North local government area was obtained from the State office of Agricultural Development Programme (ADP). This made up the sampling frame from which 40 farm families were randomly selected. However, data for only 30 farmers was used for the study. Data for the study was collected with the aid of structured questionnaire and interview schedule. Collected data were analyzed using frequency, percentage and chi square. Adoption of soybean products was measured by requesting respondents to mention the number of times they utilize soybean products in a week. The number of times represented the level of adoption, which was categorized as high (3 times or more weekly) or low ( $1-2$ times weekly).

\section{RESULTS AND DISCUSSION}

Table 1 shows that 33.3 percent of the respondents were between 41 and 50 years old, with an average age of 45 years. Results from the study revealed that majority (40percent) had household size of between 3 and 6 members with average household size of 6 persons. The study found that most respondents (60 percent) had between 0 and 6 years of education, with an average of 5.8 years of education, implying that they had low level of education generally.

The study revealed that majority of the respondents (66.6 percent) consumed soybean flour. This is not surprising because this is the commonest product in the open market and supermarkets in Owerri.

Table 1: Socio-economic characteristics of respondents $(\mathbf{n}=\mathbf{3 0})$

\begin{tabular}{|c|c|c|}
\hline Variables & Frequency & Percentage \\
\hline Age (years) & & \\
\hline$<30$ & 1 & 3.3 \\
\hline $30-40$ & 9 & 30.6 \\
\hline $41-50$ & 10 & 33.3 mean $=45.3$ years \\
\hline $51-60$ & 8 & 26.6 \\
\hline$>60$ & 2 & 6.6 \\
\hline Household size & & \\
\hline$<3$ & 6 & 2.0 \\
\hline $3-6$ & 12 & 40.0 \\
\hline $7-10$ & 9 & 30.0 mean $=6$ members \\
\hline $11-14$ & 1 & 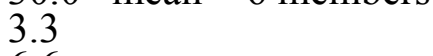 \\
\hline $\begin{array}{l}>14 \\
\text { Education }\end{array}$ & 2 & 6.6 \\
\hline $0-6$ & 18 & 60.0 \\
\hline $7-13$ & 7 & 23.3 mean $=5.8$ years \\
\hline $\begin{array}{l}14-20 \\
\text { Products most consumed }\end{array}$ & 5 & 16.6 \\
\hline Soy flour & 20 & 66.6 \\
\hline Soymilk & 7 & 23.3 \\
\hline $\begin{array}{l}\text { Gender } \\
\text { Male }\end{array}$ & 3 & 10.0 \\
\hline Female & 11 & 36.6 \\
\hline Occupation & 19 & 63.3 \\
\hline Farming & & \\
\hline Others & 20 & 66.6 \\
\hline $\begin{array}{l}\text { Marital status } \\
\text { Married }\end{array}$ & 10 & 33.3 \\
\hline Single & 23 & 76.7 \\
\hline
\end{tabular}


The study also revealed that 63.3 percent of the respondents were females, suggesting that females appreciated and utilized soybean products more. The significant role of the woman especially the wife in the household cannot be overstated. This is especially so because their decision on nutrition matters in the home make up useful part of the views in the entire household. Obasi and Obasi (2004) reported that older male members usually consult their wives for their decisions on utilization of soybean.

The study showed that 66.6 percent of the respondents involved in the study were farmers. It is obvious that farming is the major occupation of the people in the area and also in the State as a whole. The study revealed that most of the respondents were married.

\section{Table 2: Adoption of soybean products}

\begin{tabular}{lll}
\hline Rate & Frequency & Percentage \\
\hline Once a week & 3 & 10 \\
Twice a week & 6 & 20 \\
Thrice a week & 17 & 57 \\
Four times or more & 4 & 13 \\
\hline Total & 30 & 100 \\
\hline
\end{tabular}

Table 2 shows that 10 percent of the respondents utilized soybean products once a week, 20 percent utilized it twice a week, 57 percent utilized it thrice a week while 13 percent utilized it four times or more a week. The implication of the result is that majority of the respondents utilized soybean products three times a week, suggesting the adoption level was high.

Table 3: Chi square analysis showing relationship between socio-economic characteristics of respondents and adoption level

\begin{tabular}{lllll}
\hline Variables & $\mathrm{X}^{2}$ & $\mathrm{Df}$ & $\mathrm{p}$-value & \\
\hline Age & 22.833 & 4 & 0.105 & Not significant \\
Household size & 20.475 & 4 & 0.000 & Significant \\
Education & 21.837 & 2 & 0.000 & Significant \\
Gender & 7.444 & 1 & 0.000 & Significant \\
Occupation & 15.714 & 1 & 0.588 & Not significant \\
Marital status & 21.304 & 1 & 0.000 & Significant \\
\hline
\end{tabular}

From the Table 3, age showed no significant relationship with adoption of soybean product. This means that age of respondent does not influence the adoption obviously because of the perceived importance of the products. This finding agrees with that of Adedoyin et al (1998), which found no significant relationship between age and adoption of soybean utilization. Ekong (2003) also reported no significant relationship between age and adoption behaviour of farmers. Matthews-Njoku (2005) found no significant relationship between age and adoption of soil conservation technologies. 
However, Nnadi and Akwiwu (2005) found significant relationship age and adoption of crop production technologies.

Household size significantly influenced adoption of soybean products at the 0.05 level. The implication of this finding is that as the number of persons in the household increases there is the tendency that adoption will increase, and vice versa. This means that more persons in the household appreciate the benefits of soybean and its products.

Education also showed significant relationship with adoption of soybean products, implying that as level of education increases adoption also increases and vice versa. Education increases exposure to useful information and this will likely enhance their appreciation of the importance of the products. Matthews-Njoku (2005) reported significant relationship between education and adoption. Also Oladele, et al (2004) reported the influence of literacy on adoption. Obasi and Obasi (2004) also found in their study, that, among other factors, educational level influenced adoption decisions of farmers in Gboko localities of Benue State. The present study agrees with that of Tiamiyu, et al (2001) who found positive and significant relationship between literacy level and adoption of soybeans in Niger State of Nigeria. Also, Asiabaka, et al (1999) found that education significantly influenced adoption of soybean production.

Gender showed significant relationship with adoption of soybean products. The implication is that females utilized soybean products and appreciates the use also because of the nutritional importance in the home which most of them manage. The result of the study also showed that marital status significantly influenced adoption of soybean products at the 0.05 level. The implication of this finding is that married respondents utilized soybean products. It is clear that married women require the products for their children especially as the protein content has been identified to be reasonably high. This finding agrees with that of Asiabaka et al (1999) who found that marital status influenced adoption of soybean production technology.

\section{CONCLUSION AND RECOMMENDATIONS}

The adoption of soybean products was the focus of this study. From the findings of the study soybean flour recorded the highest level of adoption compared to soybean milk and other soybean products. This could be because soybean flour is more available and stores better. The study revealed that household size, education, gender and marital status significantly influenced level of adoption of soybean products. Based on the findings of the study it is recommended that there should be an increase in the awareness on the nutritional values of soybean and its products. Also Agricultural extension agents, especially Home economics extensionists should intensify efforts to teach rural women and others the proper production methods of the various soybean products especially soymilk which did not record high adoption

\section{REFERENCES}

Addo, A.A and Oguntona, C.R.B (1993) "Nutritional value of soybeans". Paper presented at training workshop of Extension workers in soybean processing and utilization, FMAWA/UNAAB, Soybean popularization, April - June 
Adedoyin, S.F., Torimiro, D.O., Joda, A.O. and Ogunkoya, A.O.(1998) "Adoption of soybeans planting, processing and utilization packages in Ago-Iwoye. Implication for extension communication towards rural child protein supplement". In: Olowu, T.A. (ed) Towards the survival of agricultural extension system in Nigeria. Proceedings of the $3^{\text {rd }}$ annual national conference of the Agricultural extension society of Nigeria, 4-6 March.

Adekunle, O.A, Ogunlade, I. and Oladele, O.I. (2003) "Adoption of soybean production technology in Kwara State, Nigeria". Journal of Extension Systems, 19 (2), 32-35.

Agrodok (Undated) "Soybean products". Agrodok series, Netherlands

Asiabaka, C. C., Obasi, P. C. and Ukpong, M. E. (1999) "Adoption of soybean production, processing and utilization in Imo State, Nigeria". Journal of Technology and Education in Nigeria, 4 (2), 89 - 97.

Ekong, E.E. (2003) An Introduction to Rural Sociology. Dove Publishers Uyo

IITA International Institute of Tropical Agriculture (1984) "On-farm performance of a new soybean and the use of soybeans in treatment of protein malnutrition in infants". IITA highlights. Ibadan: IITA

IITA (International Institute of Tropical Agriculture) (1990) How to grow and use soybean in Nigeria. IITA soybean Research. IITA - GLIP Research Monograph, No. 2. Ibadan: IITA

Matthews-Njoku, E.C. (2005) "Farmers' Adoption Of Improved Soil Conservation And Management Practices In A Rainforest Zone Of Nigeria". Global Approaches to Extension Practice, 1 (1), 24-30

National Population Commission (1992) National Population Commission, Owerri, Imo State.

Nnadi F.N. and Akwiwu, C.D (2005) "Rural Women's Response To Selected Crop Production Technologies In Imo State, Nigeria". Global Approaches to Extension Practice, 1 (1), 47-54

Obasi, C. E. and Obasi, M. O. (2004) "Influence of personal characteristics in the adoption decision of selected soybean production practices in Gboko localities of Benue State, Nigeria". Proceedings of the $37^{\text {th }}$ annual conference of the Agricultural Society of Nigeria held at Lafia.

Oladele, O. I., Adesope, O. M., Angba, A.O., Matthews-Njoku, E. C. and Kareem, A. I. (2004) "Adoption rate and continued use of selected arable crop technologies among farmers in a South Western State of Nigeria". Proceedings of the $37^{\text {th }}$ annual conference of the Agricultural Society of Nigeria (ASN), held at Calabar

Tiamiyu, S. A., Idowu, A. A. and Misari, S. N. (2001) "Determinants of soybean adoption in Niger State, Nigeria". Nigeria Agricultural Journal, 32, 152 - 161. 